\title{
Pengaruh Dari Intensitas Modal dan Tangibility Terhadap Kinerja Keuangan Perusahaan (Studi Empiris Pada Perusahaan Asuransi dan Perbankan Yang Terdaftar di Bursa Efek Indonesia (BEI) Periode 2011-2015)
}

\author{
M. Aldy ${ }^{1}$, Sany Dwita², Mayar Afriyenti ${ }^{3}$
}

Fakultas Ekonomi Universitas Negeri Padang, Jl. Prof. Dr. Hamka Air Tawar Padang

\author{
A R T I C L E I N F O \\ Article history: \\ Received 2 Juni 2018 \\ Revised 18 Juni 2018 \\ Accepted 30 Juni 2018
}

Keywords:

Capital Intensity, Tangibility, Firm Financial Performance

\begin{abstract}
A B S T R A C T
This study aims to examine the influence of capital intensity and tangibility for firm financial performance. Financial performance is the dependent variable in this study that measured by ROA (Return on Asset).Independent variable in this study are capital intensity andtangibility, using the proxies of CIR (Capital Intensity Ratio)and DER (Debt to Equity Ratio).

This study uses secondary data from financial statement of banking and insurances companies listed on Indonesian Stock exchange (IDX) for the period of 2011 to 2015. The purposive sampling technique was used to choose the study's sample, resulting with 30 banking and 10 insurances companies. The data were analyzed using multipleregression to test the hypotheses formulated in this study.

The results of this study show that partially,capital intensity and tangibility variablehave significant negative influence on capital structure. Whereas simultaneously, both have significant influence on financial performance. The resulted adjusted- $R$ square, 56.6 percent, indicatesthat5.6percentof the changes in the value of the dependent variable can be explained by the changesin the values of the independent variables, namely, capital intensity and tangibilitywhile the remaining 43.4 percentchanges are explained by other variable outside the model.
\end{abstract}

\begin{abstract}
A B S T R A K
Penelitian ini bertujuan untuk menguji pengaruh intensitas modal dan tangibility terhadap kinerja keuangan perusahaan. Kinerja keuangan merupakan variabel dependen dalam penelitian ini yang diukur dengan ROA (Return On Asset). Variabel independen yang diteliti antara lain intensitas modal dan tangibility, yang diukur dengan CIR (Capital Intensity Ratio) dan DER (Debt to Equity Ratio).

Sampel yang digunakan adalah data sekunder yang berasal dari laporan keuangan perusahaan perbankan dan asuransi yang terdaftar di Bursa Efek Indonesia (BEI) pada tahun 2011-2015. Sampel diambil dengan metode purposive sampling dan yang memenuhi kriteria pemilihan sampel. Sampel yang digunakan sebanyak 30 perusahaan perbankan dan 10 perusahaan asuransi. Metode statistik menggunakan analisis Regresi Linear Berganda dengan pengujian hipotesis uji statistik $t$ dan uji statistik F.

Hasil pengujian ini menemukan bahwa secara parsial, variabel intensitas modal dan tangibility berpengaruh secara signifikan dan negatif terhadap kinerja keuangaan perusahaan. Sedangkan untuk pengaruh secara simultan keduanya mempunyai pengaruh yang signifikan Besarnya koefisien determinasi (adjusted $R$ square) adalah sebesar 0,566. Hal ini berarti bahwa 56.6 persen variabel dependen yaitu kinerja keuangan perusahaan dapat dijelaskan oleh variabel independen yaitu intensitas modal dan tangibility sedangkan sisanya sebesar 43.4 persen kinerja keuangan dijelaskan oleh variabel atau sebab-sebab lain diluar model.
\end{abstract}

\section{PENDAHULUAN}

Dalam membuat keputusan struktur modal, ada hal penting yang harus diperhatikan oleh para manajer keuangan dalam rangka memenuhi tujuan perusahaan karena struktur modal merupakan kunci perbaikan produktivitas dan kinerja perusahaan (Kusumajaya, 2011). Keputusan struktur modal yang diambil oleh perusahaan tidak 
saja berpengaruh terhadap profitabilitas perusahaan, tetapi juga berpengaruh terhadap risiko keuangan yang dihadapi perusahaan. Risiko keuangan tersebut meliputi ketidakmampuan perusahaan untuk membayar kewajibankewajibannya dan memungkinkan tidak tercapainya laba yang ditargetkan perusahaan.

Kinerja keuangan adalah ukuran subjektif bagaimana perusahaan dapat menggunakan aset yang dimiliki untuk menghasilkan pendapatan, Myer (1977). Horne (2005) menyatakan bahwa kinerja keuangan menilai profitabilitas dan likuiditas dan menyediakan informasi berharga untuk para pemangku kepentingan dalam rangka mengevaluasi kinerja keuangan masa lalu dan posisi saat ini dari suatu perusahaan. Kesimpulan ini menyiratkan hubungan langsung antara intensitas modal dan tangibility (struktur modal) dan kinerja keuangan dari suatu perusahaan.

Horne (2005) menyatakan bahwa pengukuran kinerja keuangan meliputi hasil perhitungan rasiorasio keuangan yang berbasis pada laporan keuangan perusahaan yang dipublikasikan dan telah diaudit akuntan publik. Rasio-rasio tersebut dirancang untuk membantu para analisis atau investor dalam mengevaluasi suatu perusahaan berdasarkan laporan keuangannya. Penggunaan informasi keuangan yang disediakan sebuah perusahaan biasanya oleh analis atau investor akan menghitung rasio-rasio keuangannya yang mencakup rasio intensitas modal, leverage, dan profitabilitas perusahaan untuk dasar pertimbangan dalam keputusan investasi. Informasi keuangan tersebut mempunyai fungsi sebagai sarana informasi, alat pertanggungjawaban manajemen kepada pemilik perusahaan, penggambaran terhadap indikator keberhasilan perusahaan dan sebagai bahan pertimbangan dalam pengambilan keputusan (Harahap, 2004).

Diantara rasio kinerja terdapat ada dua ukuran yang sering digunakan, yaitu Return On Asset (ROA) dan Return On Equity (ROE). ROA memfokuskan kemampuan perusahaan untuk memperoleh earning dalam operasi perusahaan, sedangkan ROE hanya mengukur return yang diperoleh dari investasi pemilik perusahaan dalam bisnis tersebut (Mawardi, 2005). Bank Indonesia juga lebih mengutamakan nilai profitabilitas suatu bank yang diukur dengan Return On Asset (ROA) dibandingkandengan ROE karena Bank Indonesia lebih mengutamakan nilai profitabilitas suatu bank yang dikukur dengan asset yang dananya sebagian besar berasal dari simpanan masyarakat sehingga ROA lebih mewakili dalam mengukur tingkat profitabilitas bank (Dendawijaya, 2001).

Pratheepkanth (2011) menjelaskan bahwa hubungan antara struktur modal dan kinerja keuangan adalah salah satu bagian yang mendapat perhatian besar dalam literatur keuangan. Hal ini terjadi karena keputusan-keputusan berkaitan dengan struktur modal perusahaan akan memberikan dampak terhadap aktivitas-aktivitas yang dilakukan oleh perusahaan di masa depan. Pada penelitian ini, yang digunakan sebagai proksi struktur modal adalah gabungan dari Tangibility dan Capital Intensity(Gamlath, et al, 2014).

Intensitas modal adalah perputaran harta (total assets turnover), yaitu perputaran seluruh harta perusahaan yang dihitung dari penjualan dibagi dengan harta. Rasio intensitas modal menunjukkan efisiensi perusahaan dalam menggunakan seluruh asetnya untuk menghasilkan penjualan. Semakin tinggi rasio ini berarti semakin efisien penggunaan aset tersebut (Riyanto, 1995 ). Intensitas modal dalam penelitian ini diukur melalui Capital Intensity Ratio (CIR).

Tangibility adalah ukuran dari pemanfaatan aset jangka panjang yang digunakan dalam operasional perusahaan (Gamlath, et al 2014). Semakin tangible suatu perusahaan, maka akan semakin besar pula kemampuan persusahaan tersebut dalam menerbitkan surat hutang (Booth et al, 2001), jika suatu perusahaan mempunyai komposisi yang besar pada aset tetapnya, maka kesempatan untuk mendapatkan bunga yang lebih rendah akan semakin besar dan begitu pula sebaliknya. Pada dasarnya hal ini merupakan refleksi dari pengendalian manajemen pada aset tetap secara jangka panjang dan juga sebagai indikasi dari ukuran dari earning power dari aset tersebut untuk memaksimmalkan keuntungan dari pemegang saham. Tangibility dalam penelitian ini diukur melalui rasio Debt to Equity Ratio (DER).

Berikut adalah gambaran fenomena yang terjadi di lapangan tentang profitabilitas dan strukur modal industri perbankan dan asuransi yang terdaftar di Bursa Efek Indonesia (BEI), yang terjadi dalam kurun waktu 2011 sampai dengan 2015.

Tabel 1

Perkembangan KomponenPermodalan dan Kinerja Perusahaan

\begin{tabular}{|l|r|r|r|r|r|}
\hline \multirow{2}{*}{ RATIO } & \multicolumn{5}{|c|}{ PERIODE } \\
\cline { 2 - 6 } & 2011 & 2012 & 2013 & 2014 & 2015 \\
\hline CIR & 9,29 & 11,53 & 10,31 & 10,31 & 8,86 \\
\hline DER & 6,88 & 6,79 & 6,56 & 6,41 & 6,14 \\
\hline ROA & 2,94 & 2,38 & 2,41 & 2,07 & 1,79 \\
\hline
\end{tabular}

Sumber : olahan penulis 2016 
Penelitian mengenai keterkaitan struktur modal perusahaan dengan profitabilitas menunjukkan hasil yang belum konsisten. Titman \& Wessels (1988) menemukan bahwa apabila kemampuan perusahaan untuk memeroleh laba meningkat, maka struktur modal perusahaan yang di ukur dengan menggunakan leverage akan menurun. Dengan kata lain bahwa perubahan struktur modal perusahaan berbanding terbalik dengan profitabilitasnya. Demikian pula penelitian oleh Kester (1986), Rajan dan Zinglas (1995) juga memeroleh hasil yang sama dengan penelitian yang dilakukan oleh Titman \& Wessels (1988).

Penelitian ini merupakan replikasi dari penelitian yang dilakukan oleh Gamlath et al (2014) di Srilanka yang bertempat di Bursa Efek Kolombo yang menguji pengaruh Intensitas Modal dan Tangibility terhadap kinerja keuangan pada perusahaan yang terpilih di Bursa Efek Kolombo. Gamlath et al (2014) menemukan bahwa terdapat hubungan negatif antara Intensitas Modal dan Tangibility terhadap kinerja keuangan. Peneliti menilai bahwa perlu menguji penelitian yang dilakukan oleh Gamlath untuk menilai apakah memang Intensitas Modal dan Tangibility berpengaruh negatif terhadap kinerja keuangan sektor perbankan dan asuransi di Indonesia.

Peneliti memilih sektor perbankan karena sektor perbankan memiliki karakteristik yang tidak dimiliki oleh perusahaan bukan bank yaitu secara operasional bank memiliki aset tetap yang rendah, utang jangka pendeknya lebih banyak dan perbandingan antara aset dan modal sangat besar. Selain itu, perbankan juga mewakili sektor keuangan dengan karakteristiknya yang berbeda dari sektor lain baik dari sisi pencatatan akuntansi, fungsi, regulasi dan lain-lain. Dan untuk industri asuransi, penulis memilih karena ada interconnectedness dengan industri perbankan, hal ini bisa dilihat dari penyertaan DPK dari asuransi terhadap perbankan yang selalu meningkat tiap tahunnya.

\section{TELAAH LITERATUL DAN PENGEMBAN- GAN HIPOTESIS}

\section{a) Struktur Modal}

Teori struktur modal modern pertama kali dimulai oleh Franco Modigliani dan Merton $\mathrm{H}$. Miller pada tahun 1958. Modigliani-Miller (MM) menyatakan bahwa rasio utang tidak relevan dan tidak ada struktur modal yang optimal. Hasil yang diperoleh MM menunjukkan bahwa cara sebuah perusahaan akan mendanai operasinya tidak akan berarti apa-apa, sehingga struktur modal adalah suatu hal yang tidak relevan. Menurut Weston dan Brigham (2005), struktur modal yang ditargetkan adalah bauran atau perpaduan dari utang, saham preferen, saham biasa yang dikehendaki perusahaan dalam struktur modalnya. Struktur modal yang optimal adalah gabungan ekuitas yang memaksimumkan harga saham perusahaan. Gitman (2006) menjelaskan bahwa struktur modal merupakan kumpulan dana yang dapat digunakan dan dialokasikan oleh perusahaan di mana dana tersebut diperoleh dari utang jangka panjang dan modal sendiri.

Struktur modal perusahaan dibagi kedalam dua kategori antara lain sebagai berikut.

1. Struktur modal sederhana, yaitu perusahaan yang tidak mempunyai efek berpotensi saham biasa (potential diluters).

2. Struktur modal kompleks, yaitu perusahaan yang mempunyai satu atau lebih jenis efek berpotensi saham biasa.

Penggolongan struktur modal perusahaan ke dalam kategori sederhana dan kategori kompleks tidak didasarkan pada besar kecilnya skala operasi, tetapi semata-mata didasarkan pada ada atau tidak adanya efek yang berpotensi dalam saham biasa di dalam struktur modalnya.

\section{b) Kinerja Keuangan}

Menurut Fabozzi (1999), kinerja suatu perusahaan dipengaruhi oleh berbagai faktor yang secara umum dapat dibagi dalam dua kelompok, yaitu faktor internal dan faktor eksternal perusahaan. Faktor internal merupakan faktorfaktor yang berada dalam kendali pihak manajemen perusahaan, sedangkan faktor eksternal merupakan faktor-faktor yang berada di luar kendali manajemen perusahaan. dengan tujuan penelitian.

Sawir (2005) menyatakan bahwa kinerja keuangan adalah prestasi yang dicapai oleh perusahaan dalam suatu periode tertentu yang mencerminkan tingkat kesehatan dari perusahaan tersebut. Nainggolan (2004) dalam Christiani (2010) menyatakan bahwa kinerja keuangan perusahaan merupakan salah satu aspek penilaian yang fundamental mengenai kondisi keuangan perusahaan yang dapat dilakukan berdasarkan analisis terhadap rasio-rasio keuangan perusahaan, antara lain: rasio likuiditas, rasio leverage, rasio aktivitas dan rasio profitabilitas yang dicapai oleh perusahaan dalam suatu periode tertentu.

\section{c) Capital Intensity Ratio (CIR)}

Pengukuran rasio Perputaran total aset bila 
dibalik (reciprocal) akan mencerminkan rasio intensitas modal atau capital intensiveness (Brigham dan Gapensky 1996), intensitas modal menunjukkan tingkat frekuensi perputaran harta (total asset turn over) perputaran seluruh harta perusahaan dan dihitung dari penjualan dibagi dengan jumlah harta. Intensitas modal menunjukan tingkat frekuensi perputaran efisiensi di mana perusahaan menggunakan seluruh asetnya untuk menghasilkan penjualan. Semakin tinggi ukuran intensitas modal, memiliki arti semakin efisien penggunaan aset tersebut. Intensitas modal yang semakin tinggi berarti semakin efisien penggunaan aset tersebut dalam menghasilkan penjualan (Purwanti, 2010).

Atas referensi di atas, Intensitas Modal didefinisikan sebagai tingkat frekuensi perputaran harta bank yang menunjukkan tingkat efisiensi bank dalam penggunaan seluruh asetnya untuk menghasilkan penjualan. Dalam hal ini, penjualan yang dihasilkan perbankan adalah kredit yang disalurkan kepada nasabah dan premi bagi perusahaan asuransi.

\section{d) Debt to Equity Ratio (DER)}

Debt to Equity Ratio (DER) merupakan kelompok dalam rasio Levarage. Rasio ini menunjukkan komposisi atau struktur modal dari total pinjaman (hutang) terhadap total modal yang dimiliki perusahaan perusahaan dalam memenuhi kewajiban jangka panjangnya. Debt to Equity Ratio (DER) adalah perbandingan antara total utang dengan total modal. Debt to Equity Ratio (DER) digunakan untuk mengukur tingkat penggunaan hutang terhadap total shareholder's equity yang dimiliki perusahaan (Ang, 1997).

Ang (1997) menyatakan semakin besar hutang, semakin besar risiko yang ditanggung perusahaan. Semakin tinggi debt equity ratio (DER) menunjukkan komposisi total hutang (jangka pendek maupun jangka panjang) semakin besar dibanding dengan total modal sendiri, sehingga berdampak semakin besar beban perusahaan terhadap pihak luar (kreditur).

Analisis debt to equity ratio penting karena digunakan untuk mengukur tingkat penggunaan utang sebagai sumber pembiayaan perusahaan yang mencakup kewajiban lancar maupun utang jangka panjang, dalam menilai kinerja keuangan perusahaan.

\section{e) Return On Asset (ROA)}

Dalam penelitian ini, profitabilitas diukur dengan ROA dimana ROA mengukur kemampuan manajemen bank dalam mengelola asetasetnya guna memperoleh keuntungan secara keseluruhan (Lukman Dendawijaya, 2003: 120).

Return On Assets (ROA) merupakan rasio yang digunakan untuk mengukur kemampuan manajemen bank dalam memperoleh profitabilitas dan mengelola tingkat efisiensi usaha bank secara keseluruhan. Semakin besar nilai rasio ini menunjukkan tingkat rentabilitas usaha bank semakin baik atau sehat (Mahrinasari, 2003). Sedangkan menurut Bank Indonesia, Return On Assets (ROA) merupakan perbandingan antara laba sebelum pajak dengan rata-rata total asset dalam suatu periode. Rasio ini dapat dijadikan sebagai ukuran kesehatan keuangan. Rasio ini sangat penting, mengingat keuntungan yang diperoleh dari penggunaan aset dapat mencerminkan tingkat efisiensi usaha suatu bank. Dalam kerangka penilaian kesehatan bank, BI akan memberikan score maksimal 100 (sehat)apabila bank memiliki ROA > 1,5\% (Hasibuan, 2001:100).

Return on assets (ROA) digunakan untuk mengukur tingkat kembalian perusahaan atau efektifitas perusahaan dalam menghasilkan keuntungan dengan memanfaatkan total aset yang dipunyai perusahaan setelah disesuaikan dengan biaya-biaya untuk mendanai aset tersebut.Teori menunjukkan bahwa kenaikan return on assets (ROA) berarti terjadi kenaikan laba bersih dari perusahaan yang bersangkutan. Kenaikan tersebut kemudian akan menaikkan harga saham sehingga return saham yang diperoleh investor peusahaan akan semakin besar pula begitu juga sebaliknya. Return on assets (ROA) dianggap sebagai suatu ukuran efisiensi pengelolaan total aset (kekayaan) yang dimiliki perusahaan, jika rasio ini meningkat manajemen cenderung dipandang lebih efisien dari sudut total aset (kekayaan) yang dimiliki perusahaan.Komponen-Komponen Return On Asset (ROA)adalah :

1) Profit margin

Profit margin melaporkan kemampuan perusahaan menghasilkan laba dari tingkat penjualan tertentu. Profit margin bisa diinterpretasikan sebagai tingkat efisiensi perusahaan, yakni sejauh mana kemampuan perusahaan menekan biaya-biaya yang ada di perusahaan.

2) Perputaran total aset

Perputaran total aset mencerminkan kemampuan perusahaan menghasilkan penjualan dari total investasi tertentu. Rasio ini juga bisa diartikan sebagai kemampuan perusahaan mengelola aset berdasarkan 
tingkat penjualan yang tertentu. Rasio ini mengukur aktivitas penggunaan aset perusahaan.

\section{f) Return On Equity (ROE)}

Salah satu syarat utama dalam mengoperasikan suatu perusahaan adalah perusahaan tersebut mampu menghasilkan pendapatan untuk para pemegang saham, karena hal tersebut merupakan satu ukuran keberhasilan perusahaan yang dalam hal ini adalah tingkat pengembalian pendapatan yang mampu diperoleh atas common stockholders equity (Higgins, 2001:195).

Return on equity (ROE) atau sering disebut juga dengan return on common equity, yang dalam bahasa Indonesia istilah ini sering juga diterjemahkan sebagai rentabilitas saham sendiri (rentabilitas modal sendiri). Investor yang akan membeli saham akan tertarik dengan ukuran profitabilitas ini, atau bagian dari total profitabilitas yang bisa dialokasikan ke pemegang saham. Seperti diketahui, pemegang saham mempunyai klaim residual atas keuntungan yang diperoleh. Keuntungan yang diperoleh perusahaan pertama akan dipakai untuk membayar utang bunga, kemudian saham preferen, baru kemudian (kalau ada sisa) diberikan kepada pemegang saham biasa.

Return on equity (ROE) digunakan untuk mengukur tingkat pengembalian perusahaan atau efektifitas perusahaan dalam menghasilkan keuntungan dengan memanfaatkan ekuitas yang dimiliki perusahaan. Teori menunjukkan bahwa kenaikan return on equity (ROE) berarti terjadi kenaikan laba bersih dari perusahaan yang bersangkutan. Kenaikan tersebut kemudian akan menaikkan harga saham sehingga return saham yang diperoleh investor perusahaan akan semakin besar pula begitu juga sebaliknya. Return on equity (ROE) dianggap sebagai suatu ukuran efisiensi pengelolaan investasi pemegang saham, jika rasio ini meningkat manajemen cenderung dipandang lebih efisien dari sudut pandang pemegang saham.Komponen-Komponen Return On Equity (ROE) adalah:

1) Return on assets (ROA)

ROA mencerminkan kemampuan perusahaan menghasilkan laba berdasarkan aset yang dimiliki.

2) Leverage yang disesuaikan

Leverage yang disesuaikan mencerminkan efek penggandaan penggunaan utang dan saham preferen untuk menaikkan return ke pemegang saham. Leverage yang disesuaikan merupakan hasil perkalian antara common earning leverage dengan leverage struktur modal. Common earning leverage mencerminkan proporsi laba bersih yang menjadi hak pemegang saham biasa dari jumlah total laba bersih operasional. Sedangkan leverage struktur modal mencerminkan sejauh mana asset perusahaan dibiayai oleh saham sendiri. Return on equity (ROE) akan semakin besar apabila return on assets (ROA) tinggi atau leverage yang disesuaikan tinggi.

\section{g) Penelitian Terdahulu}

Dari beberapa penelitian terdahulu untuk menganalisis pengaruh struktur modal terhadap kinerja perusahaan. Penelitian-penelitian mengenai pengaruh antara variabel-variabel tersebut masih menunjukkan hasil yang beragam dalam hasil penelitian, objek penelitian, bahkan alat analisis yang digunakan.

Penelitian yang dilakukan oleh Gamlath, et al (2014) menggunakan objek 21 perusahaan perbankan dan asuransi yang terdaftar di Bursa Efek Colombo Sri Lanka. Dalam penelitiannya, struktur modal diuji dengan rasio CIR, TDR, DER, $P M, R O A$ dan ROCE. Secara keseluruhan, dari hasil penelitian tersebut, Gamlath menyatakan bahwa Intensitas Modal dan Tangibility (struktur modal) mempengaruhi secara negatif kinerja perusahaan di Sri Lanka.

Berbeda dengan penelitian yang pernah dilakukan oleh Mumtas et al. (2013) pada 83 perusahaan yang diseleksi dari indeks KSE 100 Pakistan. Dalam penelitian mereka, Mumtas et al. (2013) menguji pengaruh struktur modal terhadap kinerja perusahaan dengan variabel yang berbeda dengan Gamlath (2014). Proxy dari kinerja yang digunaka ialah (EPS) earning per share, earning ratio, (PM) operating profit margin, (ROA) return on asset dan (ROE) return on equity. Melalui uji data statistik, Mumtas et al.(2013)menyimpulkan bahwa kinerja keuangan secara signifikan dipengaruhi oleh struktur modal. Struktur modal ini dinilai secara negatif berkaitan dengan nilai pasar dan juga memunculkan risiko terkait kebijakan yang berkaitan dengan struktur modal.

Pouraghajan et al. (2012) dalam penelitiannya terhadap 80 perusahaan yang terdaftar dalam Bursa Efek Teheran untuk menilai pengaruh struktur modal terhadap kinerja keuangan menggunakan return on asset dan return on equity sebagai alat uji. Hasil penelitian mereka menunjukkan bahwa ada hubungan negatif yang signifikan antara rasio utang dan kinerja keuangan perusahaan dan terdapat hubungan positif yang 
signifikan antara asset turnover, firm size, asset tangibility ratio, dan growth opportunities terhadap pengukuran kinerja keuangan. Selain itu, penelitian ini membuktikan bahwa dengan mengurangi rasio utang, manajemen perusahaan dapat meningkatkan profitabilitas perusahaan.

Penelitian yang mencoba menganalisis pengaruh struktur modal terhadap kinerja keuangan di Indonesia ialah Yogantara dan Wijaya (2010). Tujuan dari penelitian ini adalah untuk menguji hubungan antara struktur modal dan kinerja keuangan badan usaha yang termasuk dalam industri perbankan dari 2004 sampai dengan 2008 di BEI. Control variable berupa kepemilikan institusional, ukuran, risiko, kekuatan pasar, dan struktur organisasi disertakan untuk menguji pengaruh struktur modal terhadap kinerja keuangan. Control variable berupa harga rataratapasar input, harga rata-rata pasar output, ukuran, risiko, dan kekuatan pasar disertakan untuk menguji pengaruh kinerja keuangan terhadap struktur modal. Hasil penelitian menunjukkan struktur modal dan bentuk kuadratnya, kepemilikan institusional, ukuran, risiko, kekuatan pasar, dan struktur organisasi secara serempak berpengaruh signifikan terhadap kinerja keuangan badan usaha yang termasuk dalam industri perbankan dari 2004 sampai dengan 2008 di BEI. Hasil penelitian juga menunjukan struktur modal dan bentuk kuadratnya, harga ratarata pasar input, harga rata-rata pasar output, ukuran, risiko, dan kekuatan pasar secara serempak tidak berpengaruh signifikan terhadap kinerja keuangan badan usaha yang termasuk dalam industri perbankan dari 2004 sampai dengan 2008 di BEI.

Pengaruh negatif yang signifikan dari struktur modal terhadap return on asset juga ditemukan oleh Hartati (2013). Penelitian ini dilakukan dengan menggunakan data sekunder. Teknik sampel yang digunakan adalah purposive sampling. Dari 45 perusahaan pada LQ 45 non perbankan, hanya diambil 19 perusahaan sebagai sampel, karena memiliki laporan keuangan secara lengkap tahun 2008-2011. Metode analisis yang digunakan adalah analisis regresi linier berganda. Dengan menggunakan analisis regresi, maka dapat diperoleh hasil bahwa return on asset berpengaruh negatif dan signifikan terhadap debt to equity ratio. Ukuran Perusahaan berpengaruh positif dan tidak signifikan terhadap debt to equity ratio. Pertumbuhan Aset berpengaruh positif dan tidak signifikan terhadap debt to equity ratio. Current ratio berpengaruh negatif dan signifikan terhadap debt to equity ratio. Struktur Aset berpengaruh negatif dan tidak signifikan terhadap debt to equity.

\section{h) Pengembangan Hipotesis \\ Hubungan antara CIR dan ROA}

Rasio intensitas modal adalah ukuran dari jumlah aset yang dipergunakan perusahaan untuk menghasilkan rupiah keuntungan, yang diformulasikan dengan membagi total aset perusahaan dengan penjualannya. Semakin besar intensitas modal sebuah perusahaan, membuktikan bahwa perusahaan tersebut membutuhkan aset yang lebih dibandingkan perusahaan lain dengan rasio yang lebih rendah untuk keuntungan yang sama (Capital Instensive)

Menurut Commanor dan Wilson (1967). Rasio intensitas modal merupakan salah satu informasi yang penting bagi investor karena dapat menunjukkan tingkat efisiensi penggunaan modal yang telah ditanamkan. Salah satu indikator prospek suatu perusahaan di masa mendatang yang dapat digunakan untuk menilai suatu intensitas modal mencerminkan seberapa besar modal yang dibutuhkan untuk menghasilkan pendapatan dalam merebut pasar yang di inginkan oleh perusahaan. Semakin besar intensitas modal suatu perusahaan akan berdampak pada peningkatan penjualan yang ada diperusahaan sehingga akan berdampak secara langsung terhadap kinerja keuangan.

H1 : Rasio intensitas modal berpengaruh positif terhadap ROA

\section{Hubungan antara DER dan ROA}

Debt to equity ratio merupakan rasio yang mengukur tingkat penggunaan hutang (laverage) terhadap total sharehoder's equity yang dimiliki perusahaan. Rasio ini diukur dengan cara membandingkan antara hutang perusahaan terhadap total sharehoder's equity. Hutang mempunyai dampak yang buruk terhadap kinerja perusahaan, karena tingkat hutang yang semakin tinggi berarti beban bunga akan semakin besar yang berarti mengurangi keuntungan. Semakin tinggi DER menunjukkan semakin besar beban perusahaan terhadap pihak luar, hal ini sangat memungkinkan menurunkan kinerja perusahaan, karena tingkat ketergantungan dengan pihak luar semakin tinggi. Dengan demikian hubungan antara DER dengan ROA diperkirakan negatif sebagaimana yang pernah diteliti oleh Campbel (2002).

$\mathrm{H} 2$ : DER berpengaruh negatif terhadap ROA 


\section{Rerangka Konseptual}

Berdasarkan kajian rujukan dan landasan teori serta kajian penelitian-penelitian sebelumnya, dapat disusun kerangka konseptual penelitian yang mendasari penelitian ini adalah bahwa kinerja keuangan merupakan tujuan utama yang ingin dicapai bagi manajemen perusahaan untuk meningkatkan kemakmuran pemegang saham. Kinerja keuangan untuk perusahaan-perusahaan yang go public akan tercermin pada harga sahamnya, jadi semakin tinggi harga sahamnya maka kemakmuran pemegangsaham juga akan meningkat. Beberapa studi empirik membuktikan terdapat pengaruh Intensitas modal dan Tangibility terhadap tingkat kinerja keuangan perusahaan, kemudian disusun kerangka konseptual untuk melihat hubungan-hubungan antara variabel penelitian seperti terlihat pada Gambar 1.1. Berdasarkan gambar tersebut menunjukkan bahwa penelitian ini dilakukan bertujuan untuk menguji hubungan intensitas modal dan tangibility terhadap kinerja keuangan perusahaan.

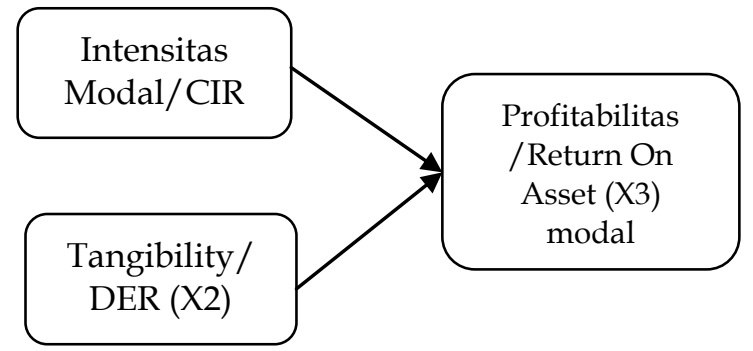

Gambar 1

Flow Rerangka Konseptual

\section{Hipotesis}

Berdasarkan teori dan latar belakang permasalahan yang telah dikemukakan sebelumnya, maka dapat dibuat beberapa hipotesis terhadap permasalahan sebagai berikut:

H1 : Rasio intensitas modal berpengaruh positif terhadap ROA

$\mathrm{H} 2$ : DER berpengaruh negatif terhadap ROA

\section{METODE PENELITIAN}

\section{Jenis Penelitian}

Penelitian ini bertujuan untuk menguji hipotesis yang menjelaskan sifat hubungan tertentu dengan investigasi korelasional. Peneliti ingin lebih lanjut melihat pengaruh Intensitas Modal dan Tangibility (Struktur Modal) terhadap kinerja keuangan sektor perbankan dan asuransi. Intervensi peneliti dalam penelitian ini rendah. Sumber data yang digunakan seluruhnya merupakan sumber data sekunder dengan jenis data adalah data documenter yaitu situs bursa efek Indonesia dan perusahaan terkait serta laporan tahunannya. Dalam penelitian ini digunakan aplikasi SPSS 20 sebagai program untuk menganalisis data.

Penelitian ini menggunakan sumber data sekunder, data diperoleh melalui internet. Secara umum, penelitian ini dilakukan di Bursa Efek Indonesia karena seluruh data diperoleh dari situs Bursa Efek Indonesia.

Berdasarkan dimensi waktu, penelitian ini termasuk dalam penelitian cross-sectional (penelitian yang dilakukan pada satu waktu tertentu) dan time series (penelitian yang dilakukan dengan mengumpulkan tipe informasi yang sama mengenai perubahan gejala dari data dalam waktu yang berbeda). Penelitian ini menggunakan data perusahaan perbankan yang terdaftar di Bursa Efek Indonesia tahun 2011-2015.

\section{Populasi dan Sampel}

Populasi dalam penelitian ini adalah seluruh perusahaan perbankan yang listed dan go public di Bursa Efek Indonesia mengacu pada periode waktu yang digunakan oleh peneliti. Sedangkan sampel pada penelitian ini dipilih melalui penarikan purposive samplingberdasarkan pertimbangan yang didasarkan pada kriteria-kriteria tertentu karena tidak semua perusahaan perbankan digunakan dalam penelitian ini. Kriteria pengambilan sampel dalam penelitian ini adalah:

1) Perusahaan perbankan dan asuransi yang tetap listing di BEI selama periode pengamatan yaitu tahun 2011-2015.

2) Perusahaan perbankan dan asuransi yang yang tidak melakukan merger selama periode 2011-2015

3) Perusahaan dan asuransi yang tidak diakuisisi selama periode 2011-2015.

4) Perusahaan perbankan dan asuransi memiliki laporan keuangan lengkap

Berdasarkan karakteristik pemilihan sampel diatas diperoleh perusahaan yang akan digunakan sebagai sampel penelitian adalah:

Tabel 2

Tabel Pemilihan Sampel

\begin{tabular}{|c|l|c|}
\hline & \multicolumn{1}{|c|}{ Jumlah Populasi total } & $\mathbf{5 4}$ \\
\hline 1. & $\begin{array}{l}\text { Perusahaan perbankan dan asuransi yang tetaplist- } \\
\text { ing di BEIselama periode pengamatan yaitu tahun } \\
\text { 2011-2015. }\end{array}$ & $\mathbf{( 1 4 )}$ \\
\hline 2 & $\begin{array}{l}\text { Perusahaan perbankan dan asuransi yang yang } \\
\text { tidak melakukan merger periode 2011-2015 }\end{array}$ & $\mathbf{( 0 )}$ \\
\hline 3. & $\begin{array}{l}\text { Perusahaan dan asuransi yang yang tidak diakuisi- } \\
\text { si selama periode 2011-2015. }\end{array}$ & $\mathbf{( 0 )}$ \\
\hline 4. & $\begin{array}{l}\text { Perusahaan perbankan dan asuransi memiliki } \\
\text { laporan keuangan lengkap }\end{array}$ & $\mathbf{( 0 )}$ \\
\hline & Jumlah Sampel & $\mathbf{4 0}$ \\
\hline
\end{tabular}




\section{Jenis dan Sumber Data}

Jenis data yang digunakan dalam penelitian ini adalah data documenter berupa informasi keuangan yang terdapat dalam website perusahaan dan website Bursa Efek Indonesia. Data tersebut merupakan data yang diterbitkan oleh perusahaan.

Sumber data yang digunakan dalam penelitian ini adalah sumber data sekunder, yaitu sumber yang tidak langsung memberikan data kepada pengumpul data, misalnya melalui orang lain atau lewat dokumen (Sugiyono, 2008). Sumber data penelitian ini diperoleh sebagai berikut.

1) Website Bursa Efek Indonesia di www.idx.co.id.

2) Website perusahaan.

\section{Teknik Pengumpulan Data}

Dalam penelitian ini pengumpulan data dilakukan dengan beberapa metode yaitu sebagai berikut.

1) Mengunduh data dari website Bursa Efek Indonesia dan website perusahaan untuk memperoleh data total Capital Intensity Ratio (CIR), Debt to Equity Ratio (DER) dan Return On Assets (ROA).

2) Pengumpulan data sebagai landasan teori serta penelitian terdahulu didapat dari dokumen-dokumen, buku, jurnal, internet serta sumber data tertulis lainnya yang berhubungan dengan informasi yang dibutuhkan.

3) Mencari website perusahaan dengan tahaptahap sebagai berikut.

a) Melihat alamat website perusahaan yang tercantum dalam Bursa Efek Indonesia.

b) Website perusahaan yang tidak tercantum dalam halaman di bursa efek Indonesia, peneliti menggunakan search engine yang umum digunakan seperti Google dan Yahoo.

c) Website perusahaan diakses untuk menguji aksesbilitasnya dan untuk keperluan pengumpulan data.

\section{Variabel Penelitian}

\section{a) Variabel Independen $\left(X_{1}\right)$}

Capital Intensity Ratio (CIR)

Capital Intensity Ratio (CIR) adalah perbandingan total aset perusahaan dengan laba operasi perusahaan pada perusahaan perbankan \& asuransi di BEI tahun 2011-2015. Satuan pengukuran CIR adalah dalam kelipatan.

$$
\text { Capital Intensity Ratio }=\frac{\text { Total Aset }}{\text { Penjualan }}
$$

b) Variabel Independen (X2)

Debt to Equity Ratio (DER)

Debt to Equity Ratio(DER) adalah perbandingan total hutang perusahaan dibagidengan ekuitas lalu dikali 100 persen, pada perusahaan perbankan \& asuransi di BEI tahun 2010-2014. Satuan pengukuran DER adalah dalam persentase.

$$
\text { Debt to Eqiuity Ratio }=\frac{\text { Total Hutang }}{\text { Ehuitas }} \times 100 \%
$$

\section{c) Variabel Dependen (Y)}

Return on Assets (ROA)

Return on Assets(ROA) adalah perbandingan laba bersihperusahaan dengantotal aset perusahaan pada perusahaan perbankan \& asuransi di BEI tahun 2010-2014. Satuan pengukuran ROA adalah dalam persen.

$$
\text { Return on Assets }=\frac{\text { Laba Bersih }}{\text { Total Aset }} \times 100 \%
$$

\section{Metode Analisis Data}

\section{a) Analisis Linear Berganda}

Penelitian ini dengan menggunakan metode kuantitatif dengan analisis regresi berganda. Analisis regresi berganda digunakan untuk menguji pengaruh antara CIR dan TDR terhadap Kinerja Keuangan yaitu ROA. Seberapa besar variabel independen mempengaruhi variabel dependen dihitung dengan menggunakan persamaan garis regresi berganda berikut:

Rumus:

$\mathrm{Y}=\mathrm{a}+\mathrm{b} 1 \mathrm{X} 1+\mathrm{b} 2 \mathrm{X} 2+\mathrm{e}$

Dimana:

$\mathrm{a}=$ konstanta

$\mathrm{b} 1, \mathrm{~b} 2, \mathrm{~b} 3, \ldots, \mathrm{bn}=$ koefisien regresi

$\mathrm{e}=$ error

$\mathrm{Y}=$ Return on Asset (ROA)

$\mathrm{X} 1=$ Capital Intensity Ratio (CIR)

$\mathrm{X} 2=$ Debt to Equity Ratio (DER)

\section{b) Uji F}

Uji F untuk melihat apakah semua variabelvariabel independen yang dimasukkan dalam model mempunyai pengaruh secara simultan tehadap variabel dependen. Hipotesis nol (H0) yang hendak diuji adalah apakah semua parameter dalam model sama dengan nol, atau :H0: $\rho 1=0$

Artinya tidak ada pengaruh yang signifikan secara bersama-sama dari seluruh variabel independen tehadap variabel dependen. Hipotesis alternatif (H1) bila semua parameter secara simultan tidak sama dengan nol, atau :

H0: $\rho 1 \neq 0$

Artinya ada pengaruh yang signifikan secara bersama-sama dari seluruh variabel independen 
terhadap variabel dependen.

Untuk menguji hipotesis ini digunakan statistik $\mathrm{f}$ dengan kriteria :

1) Quick look : bila nilai f lebih besar dari pada 4 maka $\mathrm{H}_{0}$ dapat ditolak padaderajat kepercayaan 5 persen. Dengan kata lain kita menerima hipotesis alternatif, yang menyatakan bahwa semua variabel independen secaraserentak dan signifikan mempengaruhi variabel dependen.

2) Membandingkan nilai $F$ hasil perhitungan dengan nilai $F$ menurut tabel.Bila nilai $F$ hitung lebih besar dari pada nilai $\mathrm{F}$ tabel, maka $\mathrm{H}_{0}$ ditolak danmenerima $\mathrm{H}_{1}$

c) Uji t

Uji statistik $\mathrm{t}$ menunjukkan seberapa jauh pengaruh satu variabel penjelas/ independen secara individual dalam menerangkan variasivariasi dependen. Untuk melihat apakah variabel independen tersebut memiliki pengaruh terhadap variabel dependen, pengujian hipotesis nol (H0) dilakukan dengan melihat apakah suatu parameter (bi) sama dengan nol atau : $\mathrm{HO}: \mathrm{bi}=0$

Untuk hipotesis alternatifnya (Ha), diuji apakah parameter variabel lebih besar dari nol, atau : $\mathrm{Ha}: \mathrm{bi}>0$

Apabila nilainya lebih besar dari pada nol, maka variabel independen tersebut merupakan penjelas yang signifikan terhadap variabel dependen. Cara melakukan uji t sebagai berikut :

1) Quick look : bila jumlah degree of freedom (df) adalah 20 atau lebih, dan derajatkepercayaan sebesar 5 persen, maka H0 yang menyatakan $\mathrm{bi}=0$ dapat ditolak bilanilai $\mathrm{t}$ lebih besar dari 2 (dalam nilai absolut).Dengan kata lain kita menerima hipotesis alternatif, yang menyatakan bahwa satuvariabel independen secara individual mempengaruhi variabel dependen,

2) Membandingkan nilai statistik $t$ dengan nilai titik krisis menurut tabel.Apabila nilai statistik $\mathrm{t}$ hasil perhitungan lebih tinggi dibandingkan $\mathrm{t}$ tabel, kitamenerima hipotesis alternatif yang menyatakan bahwa suatu variabel independensecara individual mempengaruhi variabel dependen.

\section{d) Koefisien Determinasi $\left(\mathbf{R}^{2}\right)$}

Koefisien Determinasi (R2) untuk mengukur seberapa jauh kemampuan modeldalam menerangkan variabel dependen. Nilai Kd adalah antara 0 dan 1 . Nilai Ryang kecil berarti kemampuan variabel-variabel Independen dalam menerangkanvariabel dependen sangat terbatas. Nilai yang mendekati 1 berarti variabel independen memberikan hampir semua informasi yang dibutuhkan untuk memprediksi variasi variabel independen.

Kelemahan Koefisien Determinasi (R2) adalah bias terhadap jumlah variabelindependen yang dimasukkan ke dalam model. Setiap tambahan satu variabelindependen maka $R$ pasti akan meningkat walaupun belum tentu variabel yangditambahkan berpengaruh secara signifikan terhadap variabel dependen. Olehkarena itu, digunakan nilai adjusted R2, karena nilai adjusted R2 dapat naik atauturun apabila suatu variabel independen ditambahkan ke dalam model.

\section{HASIL PENELITIAN DAN PEMBAHASAN}

Pada bagian ini akan dipaparkan hasil pengolahan data berikut analisisnya untuk menjawab hipotesis penelitian yang telah dikemukakan sebelumnya.

\subsection{Uji Asumsi Klasik}

\section{a) Uji Normalitas}

Dari tabel 3 (Lampiran 1) menunjukkan bahwa perolehan sigma K-S (nilai a) dari hasil uji Kolmogorov Smirnov dapat dilihat bahwa nilai signifikansi sebesar 0,690. Hal ini artinya bahwa nilai tersebut signifikan karena lebih besar dari nilai signifikansi sebesar 0,05 atau $0,646>0,05$, jadi dapat disimpulkan bahwa data model residual terdistribusi normal.

\section{b) Uji Multikolinearitas}

Berdasarkan tabel4 (Lampiran 1) hasil perhitungan nilai tolerance CIR 0,861 >0,10, DER 0,861 > 0,10 menunjukkan tidak ada variabel independen yang memiliki nilai tolerance kurang dari 0,10 yang berarti tidak ada korelasi antar variabel independen yang nilainya lebih dari $95 \%$. Hasil perhitungan nilai Variance Inflaction Factor (VIF) juga menunjukkan hal yang sama tidak ada satu variabel independen yang memiliki nilai VIF lebih dari 10. Nilai VIF CIR 1,161 < 10, DER 1,161 < 10. Jadi dapat disimpulkan bahwa tidak ada multikolinearitas antar variabel independen dalam model regresi.

\section{c) Uji Autokolerasi}

Hasil uji DW dalam tabel tabel 5 (Lampiran 1) menunjukkan nilai DW sebesar 1,857. Apabila dibandingkan dengan tabel range nilai DW untuk ketentuan autokorelasi, hasil perhitungan yaitu sebesar 1,857 berada pada range 1,55 - 2,46 yang berarti tidak terdapat gejala autokorelasi. 


\section{4) Uji Heterokedastisitas}

Salah satu cara untuk mengetahui ada tidaknya heteroskedastisitas dalam suatu model regresi linear berganda adalah dengan melihat grafik scatterplot antara nilai prediksi variabel terikat yaitu SRESID dengan residual error yaitu ZPRED. Jika tidak ada pola tertentu dan titik menyebar diatas dan dibawah angka 0 pada sumbu Y, maka tidak terjadi heteroskedastisitas. Grafik scatterplot ditunjukkan pada gambar2 (Lampiran 1)

\subsection{Analisis Regresi Linear Berganda}

Analisis ini digunakan untuk mengetahui pengaruh variabel bebas (Independen) yaitu Capital Intensity Ratio (X1) dan Debt to Equity Ratio (X2) terrhadap variabel terikat (Dependen) yaitu Return On Asset (Y). Perhitungan dilakukan dengan menggunakanbantuan program Statistics Package For Social Science (SPSS) versi 22.0. Adapun hasil bisa dilihat pada tabel 6 (lampiran1), dengan persamaan:

ROA $=0,060-0,002$ CIR-0,003DER

\subsection{Uji Hipotesis}

Pengujian hipotesis merupakan pengujian yang berguna mencari kebenaran. Tujuan pengujian ini adalah untuk mengetahui hasil penelitian yang berkaitan dengan pengaruh Capital Intensity Ratio (X1) dan Debt to Equity Ratio (X2) terhadap ROA. Dalam penelitian ini analisis yang digunakan adalah sebagai berikut:

1) Uji Parsial (Uji-t statistik)

Hasil uji parsial dari tiap variabel CIR dan DER dapat dilihat pada tabel 7 (Lampiran 1)

a. Berdasarkan hasil perhitungan tersebut diperoleh nilai koefisien CIR sebesar $-0,002$ yang berarti berpengaruh negatif. Signifikansi untuk variabel CIR sebesar 0,00 lebih kecil $0,05(0,00<0,05)$ yang berarti berpengaruh secara signifikan, maka dapat disimpulkan bahwa hipotesis kerja $\mathrm{H} 1$ yang berbunyi "Intensitas modal berpengaruh positif terhadap kinerja keuangan.", ditolak.

b. Berdasarkan hasil perhitungan tersebut diperoleh nilai koefisien DER sebesar - 0,003 yang berarti berpengaruh negatif. Signifikansi untuk variabel DER sebesar 0,00 lebih kecil $0,05(0,00<0,05)$ yang berarti berpengaruh secara signifikan, maka dapat disimpulkan bahwa hipotesis kerja H1 yang berbunyi "Tangibilty berpengaruh negatif terhadap kinerja keuangan.", diterima.
2) Uji Simultan (Uji-F statistik)

Uji F statistik digunakan untuk mengetahui ada tidaknya pengaruh signifikan semua variabel independen (bebas) yang meliputi Capital Intensity Ratio (X1) dan Debt to Equity Ratio (X2) secara bersama-sama atau simultan terhadap variabel dependen (terikat) yaitu kinerja keuangan yang dinilai dengan ROA.

Berdasarkan hasil perhitungan pada tabel 8 (Lampiran 1) tersebut nilai $\mathrm{F}$ hitung $=119,555$ dengan probabilitas 0 di bawah 0,05 . Hal ini berarti menunjukkan ada pengaruh yang signifikan dari variabel independen CIR dan DER, secara simultan terhadap kinerja perusahaan (ROA) yaitu variabel dependen.

\subsection{Koefisien Determinasi}

Koefisien determinasi (R2) pada intinya mengukur seberapa jauh kemampuan model dalam menerangkan variasi variable dependennya. Nilai Koefisien determinasi (R2) yang mendekati satu berarti variabel-variabel independennya menjelaskan hampir semua informasi yang dibutuhkan untuk memprediksi variable dependen (Ghozali, 2005). Hasil perhitungan Koefisien Determinasi penelitian ini dapat terlihat pada tabel 7 (Lampiran $1)$,

Berdasarkan output SPSS tampak bahwa dari hasil perhitungan diperoleh Nilai koefisien determinasi (R2) sebesar 0,571. Dengan kata lain hal ini menunjukkan bahwa besar presentase variasi ROA (Variabel Dependen) yang bisa dijelaskan oleh variabel bebas yaitu CIR dan DER sebesar 57,1\%, sedangkan sisanya sebesar $42,9 \%$ dijelaskan oleh variabel-variabel lain diluar model atau faktor lain di luar variabel bebas tersebut.

\section{PENUTUP \\ Simpulan}

Berdasarkan hasil analisis data yang diuraikan pada bagian sebelumnya, maka kesimpulan dari uji hipotesis yang dilakukan pada penelitian ini dengan menggunakan analisis diskrimian adalah sebagai berikut:

1. Secara simultan struktur modal (Capital Intensity Ratio dan Debt to Equity Ratio) mempunyai pengaruh yang signifikan terhadap kinerja perusahaan (Return On Asset) pada perusahaan perbankan dan asuransi yang terdapat di Bursa Efek Indonesia Periode 2011-2015.

2. Secara parsial variabel CIR dan DER memiliki pengaruh terhadap ROA Berdasarkan hasil penelitian, pengaruh CIR dan DER secara parsial adalah sebagai berikut: 
a. Variabel CIR berpengaruh signifikan secara negatif terhadap ROA pada perusahaan perbankan dan asuransi yang terdaftar di Bursa Efek Indonesia tahun 2011-2015 artinya setiap peningkatan rasio capital intensity ratio akan mengurangi rasio retun on asset.

b. Variabel DER berpengaruh signifikan secara negatif terhadap ROA pada perusahaan perbankan dan asuransi yang terdaftar di Bursa Efek Indonesia tahun 2011-2015 artinya setiap peningkatan rasio debt to equity ratio akan mengurangi rasio retun on asset

\section{Keterbatasan Penelitian}

Penelitian ini mempunyai keterbatasanketerbatasan yang dapat dijadikan bahan pertimbangan bagi peneliti berikutnya agar mendapatkan hasil yang lebih baik lagi.

1. Data yang disajikan merupakan data panel dengan cukup banyak sampel yang digunakan. Data panel yang lebih mendekati data cross section pada dasarnya memang memiliki resiko tidak signifikan yang cukup besar. Hal ini disebabkan oleh penggunaan sampel yang cukup besar menambah kemungkinan adanya data yang outlier dan bertambahnya derajat kebebasan, walaupun sudah di eliminasi menjadi minimal. Meski demikian, semakin banyak sampel yang digunakan maka akan semakin mewakili populasi.

2. Data yang digunakan pada penelitian hanya laporan keuangan bank umum dan asuransi konvensional yang terdaftar di BEI sehingga untuk menggambarkan keadaan seluruh bank umum dan asuransi konvensional di Indonesia, termasuk diantaranya bank pembangunan daerah serta bank-bank swasta yang tidak go public, bank syariah, asuransi syariah dan asuransi umum lainnya yang belum dapat terwakilkan sepenuhnya.

\section{Saran}

Dari kesimpulan dan keterbatasan yang telah diuraikan diatas, maka dalam kesempatan ini penulis mencoba untuk memberikan saran-saran sebagai berikut:

1. Menambah kategori perusahaan yang dijadikan sampel penelitian misalnya seluruh perusahaan yang terdaftar di Bursa Efek Indonesia (BEI), sehingga penelitian selanjutnya dapat digeneralisasikan.
2. Peneliti selanjutnya diharapkan memasukkan lebih banyak variabel selainrasiokeuangan yaitu variabel non keuangankedalam model, sepertikondisiekonomi yang dapat diukur antara lain dengan menggunakan tingkat inflasi, tingkat bunga pinjaman, indeks harga konsumen umum, rata-rata sektorindustri dan lainnya.

\section{DAFTAR PUSTAKA}

Azis A.dan G. H. Lawson. 1989. Cash Flow Reporting and Financial Distress Models:Testing and Hypotheses. Financial Management 19, No. 1, Spring: 55-63

Almilia, Luciana Spica. 2004. Analisis Faktor-Faktor yang Mempengaruhi Kondisi Financial Distrees suatu Perusahaan yang Terdaftar di Bursa Efek Jakarta. Jurnal Riset Akuntansi Indonesia Vol. 7, No. 1, Januari 2004 hal 1-22.

Atmini, S., Wuryana. 2005. Manfaat Laba dan Arus Kas Untuk Memprediksi Kondisi Financial Distress pada Perusahaan Textile Mill Products dan Apparel And Other Textile Products yang Terdaftar di Bursa Efek Jakarta. Makalah yang disampaikan pada Simposium Nasional Akuntansi VIII. Solo, 15-16 September.

Belkaoui, Ahmed Riahi. 2001. Teori Akuntansi Buku 2. Jakarta: Salemba Empat.

Chairi, Anis dan Iman Ghozali. 2001. Teori Akuntansi. Semarang: Badan Penerbit Universitas Diponegoro.

Fahmi, Irham.2012. Analisis Laporan Keuangan. Bandung: Alfabeta.

Ghozali, Imam, 2002, Aplikasi Analisis Multivariat dengan Program SPSS, BP Undip, Semarang.

Harahap, Sofyan Syafri. 1996. Teori Akuntansi: Laporan Keuangan. Jakarta: Bumi Aksara.

Idris. 2010. Aplikasi Model Analisis Data Kuantitatif dengan Program SPSS. Padang. Fakultas Ekonomi Universitas Negeri Padang.

Ikatan Akuntan Indonesia. 2012. Pernyataan Standar Akuntansi No. 2. Penerbit Salemba Empat. Jakarta.

Marcelina, Pandu Dian. 2011. Analisis Laba dan Arus Kas dalam Memprediksi Financial Distress Perusahaan. Skripsi. Jember : Universitas Jember.

McCue, M.J. 1991. The Use of Cash Flow to Analyze Financial Distress in California Hospitals. Hospital and Health Service Administration, Vol. 36.

Rahmat. 2009. "Laba Akuntansi". http://blog.re.or.id/labaakuntansi.htm.(diakses 
tanggal 18 september 2011)

Suwardjono. 2005. Teori Akuntansi Perekayasaan Pelaporan Keuangan. Edisi Ketiga. Yogyakarta: BPFE.

Suryarini, 2004.Analisis Diskriminasi Dalam Memprediksi Kondisi Distress dan Non Distress Pada Perusahaan Manufaktur di Bursa Efek Jakarta. Tesis.Jember : Universitas Jember.

Wahyuningthyas Fitria, 2010. Penggunaan Laba Dan Arus Kas Untuk Memprediksi Kondisi
Financial Distress Studi Kasus Pada Perusahaan Bukan Bank Yang Terdaftar Di BEI Periode Tahun 2005-2008.Skripsi Akuntansi. Universitas Diponegoro. Semarang.

Widianingrum, Desika. 2008. Manfaat Informasi Laba dan Arus Kas untuk Memprediksi Kondisi Financial Distress Perusahaan (Studi Empiris pada Emiten Industri barang Konsumsi di BEI). Skripsi. Jember : Universitas Jember.

www.idx.co.id 


\section{LAMPIRAN}

Uji KS

Tabel 3

One-Sample Kolmogorov-Smirnov Test

\begin{tabular}{|ll|r|}
\hline & & $\begin{array}{r}\text { Unstandardized } \\
\text { Residual }\end{array}$ \\
\hline N & Mean & 183 \\
Normal Parameters ${ }^{\mathrm{a}, \mathrm{b}}$ & Std. Deviation & $0 \mathrm{E}-7$ \\
& Absolute &, 01374650 \\
Most Extreme Differences & Positive &, 055 \\
& Negative &, 055 \\
Kolmogorov-Smirnov Z & &,- 040 \\
Asymp. Sig. (2-tailed) & &, 739 \\
\end{tabular}

Uji Multikolineari-

Asymp. Sig. (2-tailed)

, 646

a. Dependent Variable:

a. Test distribution is Normal.

tas

b. Calculated from data.

ROA

Coefficients $^{\mathrm{a}}$

\begin{tabular}{|ll|r|r|}
\hline \multirow{2}{*}{ Model } & \multicolumn{2}{|c|}{ Collinearity Statistics } \\
\cline { 2 - 4 } & (Constant) & Tolerance & \multicolumn{2}{|c|}{ VIF } \\
\hline \multirow{3}{*}{1} & CIR &, 861 & 1,161 \\
& DER &, 861 & 1,161 \\
\hline
\end{tabular}

Tabel 5

Uji Autokorelasi

Model Summary

\begin{tabular}{|l|r|r|r|r|r|}
\hline Model & \multicolumn{1}{|c|}{$\mathrm{R}$} & $\mathrm{R}$ Square & \multicolumn{1}{c|}{$\begin{array}{c}\text { Adjusted R } \\
\text { Square }\end{array}$} & $\begin{array}{c}\text { Std. Error of the } \\
\text { Estimate }\end{array}$ & Durbin-Watson \\
\hline 1 &, $755^{\mathrm{a}}$ &, 571 &, 566 &, 01382 & 1,857 \\
\hline
\end{tabular}

a. Predictors: (Constant), DER, CIR

b. Dependent Variable: ROA

Gambar 2

Uji Heterokedastisitas

Scatterplot

Dependent Variable: ROA

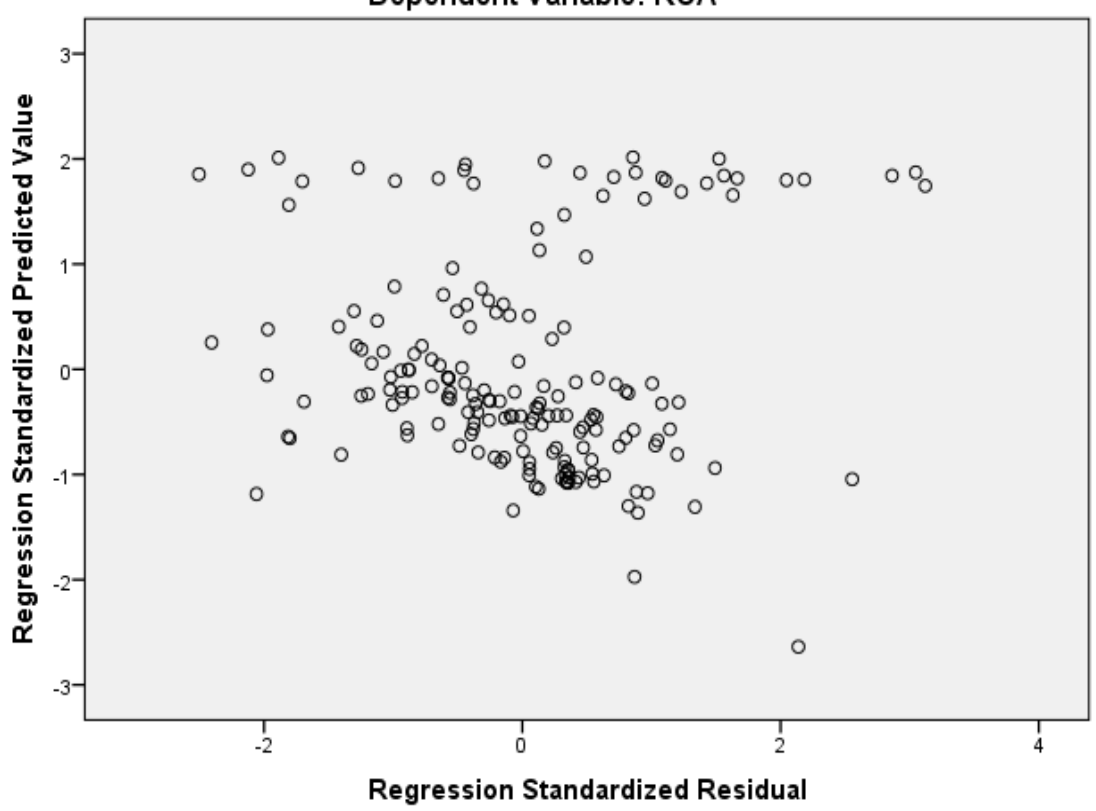


Tabel 6

Analisis Regresi Linear Berganda

\begin{tabular}{|c|c|c|c|c|c|c|}
\hline \multirow{2}{*}{\multicolumn{2}{|c|}{$\begin{array}{l}\text { Tabel 4.6Analisis } \\
\text { ReModel }\end{array}$}} & \multicolumn{2}{|c|}{ Unstandardized Coefficients } & Standardized & \multirow[t]{2}{*}{$\mathrm{t}$} & \multirow[t]{2}{*}{ Sig. } \\
\hline & & B & Std. Error & Beta & & \\
\hline \multirow{3}{*}{1} & (Constant) & ,060 & ,003 & & 22,472 &, 000 \\
\hline & CIR &,- 002 & ,000 &,- 381 & $-6,150$ &, 000 \\
\hline & DER &,- 003 & ,000 &,- 458 & $-7,389$ & ,000 \\
\hline
\end{tabular}

a. Dependent Variable: ROA

Tabel 7 Uji t

\begin{tabular}{|c|c|c|c|c|c|c|}
\hline \multirow{2}{*}{\multicolumn{2}{|c|}{ Model }} & \multicolumn{2}{|c|}{ Unstandardized Coefficients } & \multirow{2}{*}{$\begin{array}{c}\text { Standardized } \\
\text { Coefficients } \\
\text { Beta }\end{array}$} & \multirow[t]{2}{*}{$t$} & \multirow[t]{2}{*}{ Sig. } \\
\hline & & B & Std. Error & & & \\
\hline \multirow{3}{*}{1} & (Constant) & ,060 & ,003 & & 22,472 & ,000 \\
\hline & CIR &,- 002 & 000 &,- 381 & $-6,150$ & ,000 \\
\hline & DER &,- 003 & 000 &,- 458 & $-7,389$ & ,000 \\
\hline
\end{tabular}

a. Dependent Variable: ROA

Tabel 7 Koefisien Determinasi (R2)

\begin{tabular}{|l|r|r|r|r|r|}
\hline Model & $\mathrm{R}$ & $\mathrm{R}$ Square & $\begin{array}{c}\text { Adjusted R } \\
\text { Square }\end{array}$ & $\begin{array}{c}\text { Std. Error of the } \\
\text { Estimate }\end{array}$ & Durbin-Watson \\
\hline 1 &, $755^{\mathrm{a}}$ &, 571 &, 566 &, 01382 & 1,857 \\
\hline
\end{tabular}

a. Predictors: (Constant), DER, CIR

b. Dependent Variable: ROA

Tabel 8

Uji F

ANOVA $^{a}$

\begin{tabular}{|rl|r|r|r|r|r|}
\hline Model & & Sum of Squares & \multicolumn{1}{c|}{$\mathrm{df}$} & Mean Square & $\mathrm{F}$ & Sig. \\
\hline \multirow{2}{*}{1} & Regression &, 046 & 2 &, 023 & 119,555 &, $000^{\circ}$ \\
& Residual &, 034 & 180 &, 000 & & \\
& Total &, 080 & 182 & & & \\
\hline
\end{tabular}

a. Dependent Variable: ROA

b. Predictors: (Constant), DER, CIR 